\title{
Mathematical Communicaton Capability and Learning Motivation by Using Means-Ends Analysis (MEA) Learning Model in Grade VIII Students at MTs. Al-Washliyah Tembung
}

\author{
Rahimatul Islami Elmujahidah* Mulyono Humuntal Banjarnahor \\ State University of Medan, Jl. Willem Iskandar Psr. V Medan, Indonesia
}

\begin{abstract}
Abstact
This purposes of this research are: (1) the improvement communication ability and learning motivation mathematically of the students by using Means ends Analysis (MeA) and conventional learning, (2) the interaction between Means Ends analysis (MeA) model and first mathematics ability of students for improve communication ability and learning motivation mathematically. This research was conducted in MTs.Alwashliyah Tembung Kabupaten Deli Serdang. The kinds of research was quasi-experiment. The population of this research was all student MTs. Al-washliyah Tembung while the sample devided by two kinds they are VIII1 classas experiment and VIII-2 as control class. The sums of student for each class are 32 students. The sampling was done through purposive sampling technique. The research instrument which used were a test of mathematical communication ability and questionnaire of student learning motivation mathematically. The statistical hypothesis testing in this research used two way ANOVA in the SPSS programme. The results showed that (1) the improvement the student's communication ability and motivation to learn of students who received means ends analysis learning was higher than the improvement of communication ability and learning motivation who received conventional learning. The average of the improvement mathematical communication of students by using Means ends Analysis (MeA) learning and conventional learning are 0.598 and 0.498 , and the average of students by using Means ends Analysis (MeA) and conventional learning are 0.379 and 0.236 . (2) no interaction between learning model and first ability mathematics of students in the improvement ability mathematical communication and students learning motivation.
\end{abstract}

Keywords: Means ends Analysis (MeA Learning), Mathematical Communication Ability, Learning Motivation. DOI: $10.7176 / \mathrm{JEP} / 10-32-05$

Publication date: November $30^{\text {th }} 2019$

\section{Introduction}

Mathematics is a subject that is considered difficult and boring for many students, so that learning is very necessary in how to construct and create mathematical models to be a good solution to problems.

According to Soejadi (2004) mathematics education has two major objectives, namely: (1) A formal objective that puts pressure on children's reasoning and the formation of personal children, (2) Material goals that put pressure on the application of mathematics and the ability to solve mathematical problems. This is in accordance with the mathematics learning objectives formulated by the National Council of Teacher of Mathematics (2000), namely: (1) learning to communicate (mathematical communication), (2) learning to reason (mathematical reasoning), (3) learning to solve problems (mathematical problem solving), (4) learning to associate ideas (mathematical connections), (5) forming positive attitudes towards mathematics (positive attitudes toward mathematics).

According to Sanjaya (2009) there are three functions that teachers must do in teaching, namely teachers as planners, informants, and teachers as evaluators. This opinion is in line with what was stated by Hamalik (2003), that operationally there are five main variables that play a role in the teaching and learning process, namely: teaching goals, subject matter, methods and teaching techniques, teachers, students and logistics.

Mathematical communication skills need to be mastered by students because in the world of education can not be separated from the role of communication. Saragih (2007) states that communication skills in mathematics learning need to be considered, this is because mathematical communication can organize and consolidate students' mathematical thinking both orally and in writing. Baroody (Ansari, 2012) there are at least 2 important reasons that make communication in mathematics learning need to be the focus of attention, namely (1) mathematics as language (mathematics as a language); mathematics is not just a tool to aid thinking, a tool for finding patterns, or solving problems but also mathematics "an invaluable tool for communicating various ideas clearly, precisely, and succintly, and (2) mathematics learning as social activity; as a social activity, with the interaction between students, with the teacher in communicating mathematical ideas.

While Greenes and Schulman (Ansari; 2009) that mathematical communication is (1) central power for students in formulating mathematical concepts and strategies (2) capital of success for students towards approaches and solutions in mathematical exploration and investigation (3) a place for students to communicate with their friends to obtain information, share thoughts and discoveries, brainstorm, assess and sharpen ideas. 
The same thing was also stated by Greenes and Schulman (Ansari; 2009) which states that mathematical communication skills can occur when students (1) declare mathematical ideas through speech, writing, demonstration, and visualize them in different types, (2) Understanding, interpret, and assess ideas presented in writing, verbally, or in visual form, (3) Construct, interpret and connect various representations of ideas and their relationships. But the reality in the field, from Ansari's research (2009) explains that "High School students in Aceh Province on average are less skilled in communicating to convey information such as conveying ideas and asking questions and responding to other people's questions or opinions.

In addition to communication skills, one of the things that needs to be considered in conducting learning activities is learning motivation. Many students are not performing well. Hilgard (Sanjaya; 2009) says that motivation is a condition that is contained in someone who causes someone to do certain activities to achieve certain goals. In teaching and learning activities, motivation is said to be the overall driving force in students that gives rise to learning activities, which will ensure the continuity of student learning activities and provide direction in learning activities, so that the desired goals of students can be achieved, thus motivation arises from within a person because of the drive to achieve learning goals.

Motivation to learn in the beginning is a natural tendency found in the individual. His role is to foster enthusiasm in activities so that he will feel happy in learning. Uno (2009) also defines the essence of learning motivation is internal and external encouragement of individuals who are learning to make behavioral changes.

High motivation can activate students' mathematics learning activities. Slavin (2009) mentions motivation is an internal process that activates guiding and maintaining behavior from time to time. According to Sanjaya (2009) indicators arouse student learning motivation can be classified as follows: (a) clarify goals to be achieved, (b) arouse student interest, (c) create a pleasant atmosphere in learning, (d) reasonable praise for each success students, (e) assessment, (f) comments on student work results, (g) create competition and cooperation. So that the existence of semanagat for students will make optimal learning.

Adjustment of mathematics learning with the surrounding environment is supported by innovative learning models (Antonius, 2006). The teacher can make several efforts to attract attention and increase students' motivation to learn mathematics, among others: linking the material being studied with everyday life so students know the benefits of learning mathematics so that they can solve various problems both math problems themselves, other subject matter and problems in everyday life (Antonius, 2006).

Apart from learning motivation itself, the learning model is also very instrumental so that the material can be understood and easily understood by students. Learning models are conceptual frameworks that describe systematic procedures in organizing learning experiences to achieve certain learning goals. One mathematical learning model that can be used to develop communication skills and learning motivation is the Means-ends Analysis (MeA) learning model. MEA is learning that gives students the opportunity to actively construct their own knowledge, and can help students solve mathematical problems. MEA is a process or method that can be done to solve a problem into two or more sub-objectives and then work in succession in each of the subobjectives. The MEA stages involve the process of problem solving and communication at each step. In the first stage, problem solving is required to read and interpret meanings and problems. In the second stage, he must observe and make predictions, then gather information. In the third stage, students are required to communicate and explain their thoughts about mathematical ideas, using mathematical language to present ideas that describe relationships and modeling.

Choridah (2013) suggested that communication skills are very important to be raised so students are actively involved in learning and eliminating the impression of mathematics is a difficult and frightening lesson.

Every child born has the motivation to learn so that it cannot be denied that communication is a tool in motivating mathematics learning. In addition to learning factors, there are other factors that can contribute to students' mathematical abilities and attitudes towards students' mathematics learning, namely the students' Early Mathematics Ability (KAM) group, which is classified into high, medium and low groups. Early mathematical ability is a prerequisite that students must have in order to be able to take lessons smoothly.

\section{Method}

This study was categorized into quasy experiment. The study design used in this study was a pretest posttest control group design. There were sample groups in this study, namely the experimental group and the control group were given the PAM test, pretest, and posttest using equivalent instruments. The independent variable is the Means-ends Analysis (MeA) learning model while the dependent variable is mathematical communication skills and student learning motivation. The control variable is students' initial mathematical abilities (KAM).

\subsection{Research Population and Samples}

The population in this study were all MTs Al-Washliyah Tembung students in the 2018/2019 academic year. The sampling technique in this study was to use the purpose sampling technique of all class VIII students, namely class VIII-1 as the experimental class with the treatment of Means-ends Analysis (MeA) and VIII-2 learning 
models as a control class with conventional learning.

\subsection{Instrument Data Engineering}

The data of this study were obtained from the test of the initial mathematical abilities, pretest and posttest mathematical communication skills, as well as the pretest and posttest questionnaire of student learning motivation. Data analysis in this study consisted of normality testing, homogeneity testing, and hypothesis testing. The statistical hypothesis testing in this study used the two-way ANAVA formula, all statistical calculations using the help of the SPSS 22 computer program.

Syahputra (2016) states that the statistical model of this research experiment is:

$$
Y_{i j k}=\mu+\alpha_{i}+\beta_{j}+(\alpha \beta)_{i j}+\varepsilon_{i j k}
$$

with: $\quad$ i $: 1,2,3$

$$
\begin{array}{ll}
\mathrm{j} & : 1,2 \\
\mathrm{k} & : 1,2, \ldots \ldots . .
\end{array}
$$

Information:

$Y_{i j} k$ : observation of the students' mathematical communication skills scores, on the first

KAM, which gets the jth learning model

$\mu \quad$ : general average

$\alpha_{i} \quad$ : additive influence from i-KAM

$\beta_{j} \quad$ : additive influence of the jth learning model

$(\alpha \beta)_{i j} \quad$ : the influence of the interaction of the first PAM and the jth learning model

$\varepsilon_{i j k} \quad$ : error component.

\section{Results}

The results showed that the improvement of students 'mathematical communication skills taught with Means Ends Analysis (MeA) learning model was higher than the increase in students' mathematical communication skills taught with ordinary learning models. This can be seen from Table 1 the calculation of the results of the two-way ANAVA test.

Table 1. ANAVA Results Effect of Learning on Student Mathematical Communication Capabilities Tests of Between-Subjects Effects

Dependent Variable: Mathematics Communication Ability

\begin{tabular}{|c|c|c|c|c|c|}
\hline Source & Type III Sum of Squares & Df & Mean Square & F & Sig. \\
\hline Corrected Model & $.504^{\mathrm{a}}$ & 5 & .101 & 2.698 & .029 \\
Intercept & 9.605 & 1 & 9.605 & 256.869 & .000 \\
KAM & .283 & 2 & .142 & 3.791 & .028 \\
Learning & .235 & 1 & .235 & 6.276 & .015 \\
KAM * Learning & .086 & 2 & .043 & 1.152 & .323 \\
Error & 2.169 & 58 & .037 & & \\
Total & 21.923 & 64 & & & \\
Corrected Total & 2.673 & 63 & & & \\
\hline
\end{tabular}

a. R Squared $=.189$ (Adjusted R Squared $=.119)$

Based on Table 1, it can be seen that for learning factors, the value of F calculated is 6.276 and the significant value is 0.015 . Because the significant value of 0.015 is smaller than the value of the significant level of $0.05, \mathrm{H} 0$ is rejected and $\mathrm{H} 1$ is accepted. Thus, it can be concluded that the increase in students 'mathematical communication skills taught with Means ends Analysis (MeA) learning models is higher than the increase in students' mathematical communication skills taught with ordinary learning models.

The results of the next study showed that the increase in students 'mathematical learning motivation abilities taught with Means ends Analysis (MeA) learning model was higher than the increase in students' mathematical learning motivation abilities taught with ordinary learning models. The results of calculation of Two-way ANAVA can be seen in Table 2. 
Table 2. The Result of AVANA Against Student Motivation Tests of Between-Subjects Effects Dependent Variable: Learning Motivation

\begin{tabular}{|c|c|c|c|c|c|}
\hline Source & Type III Sum of Squares & $\mathrm{df}$ & Mean Square & $\mathrm{F}$ & Sig. \\
\hline Corrected Model & $.423^{\mathrm{a}}$ & 5 & .085 & 3.827 & .005 \\
Intercept & 2.700 & 1 & 2.700 & 122.243 & .000 \\
KAM & .072 & 2 & .036 & 1.635 & .204 \\
Learning & .115 & 1 & .115 & 5.199 & .026 \\
KAM * Learning & .019 & 2 & .009 & .428 & .654 \\
Error & 1.281 & 58 & .022 & & \\
Total & 7.742 & 64 & & & \\
Corrected Total & 1.704 & 63 & & & \\
\hline
\end{tabular}

a. $\mathrm{R}$ Squared $=.248$ (Adjusted R Squared $=.183$ )

Based on Table 2. it can be seen that for learning factors, obtained F count value of 5.199 and a significant value of 0.026 . Because a significant value of 0.026 is smaller than the value of a significant level of $0.05, \mathrm{H} 0$ is rejected and $\mathrm{H} 1$ is accepted. Thus, it can be concluded that the increase in students 'mathematical learning motivation abilities taught with Means ends Analysis (MeA) learning model is higher than the increase in students' mathematical learning motivation abilities taught with ordinary learning models

Research related to the influence of KAM on students' mathematical communication skills is presented in Figure 1, below:

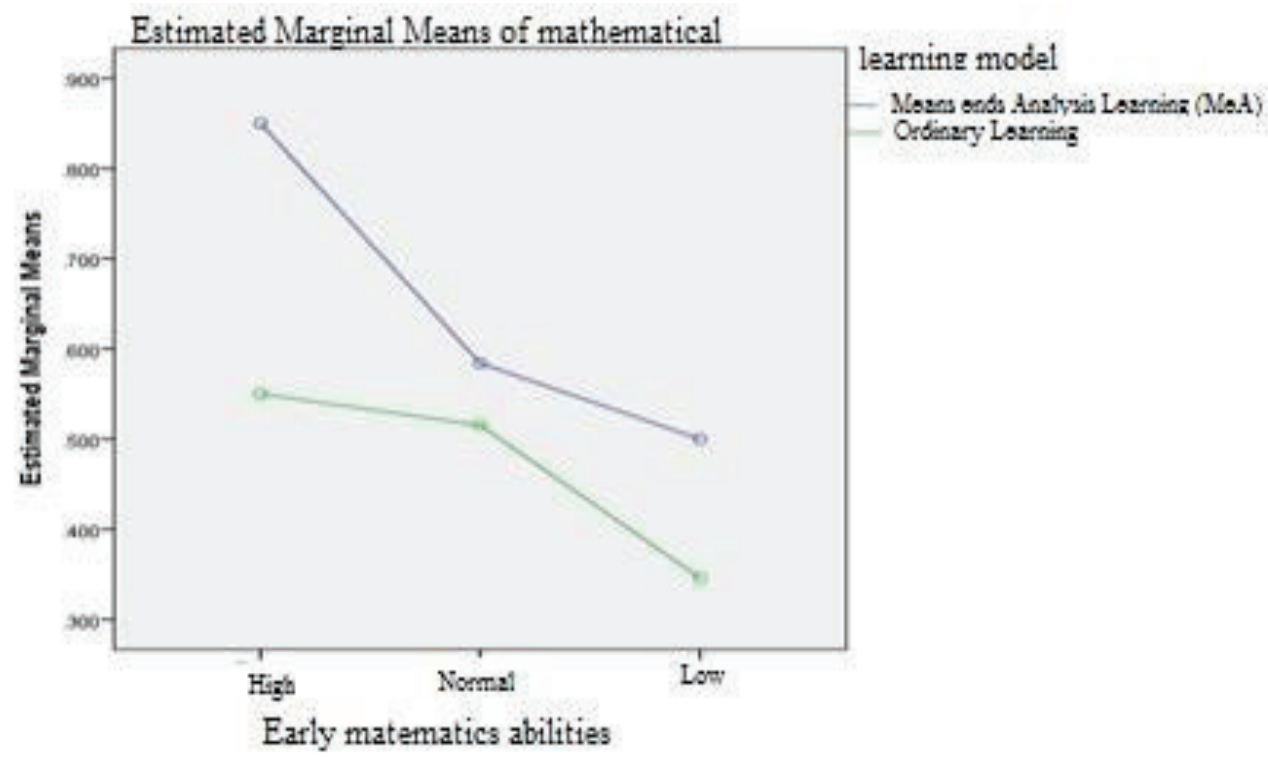

Figure 1. There is no interaction between learning models and KAM students in influencing students' mathematical communication skills.

Figure 1 above, shows that there is no interaction between the learning model and students 'initial mathematical abilities towards improving students' mathematical communication skills. The average difference in the increase in mathematical communication skills of students who get the Means Ends Analysis (MeA) learning model is more influential in achieving mathematical communication skills because the average score obtained by students in Means Ends Analysis (MeA) learning is higher than the average score obtained in learning normal So that there is no interaction between learning and students 'initial mathematical abilities towards students' mathematical communication skills can be seen clearly. This means that there is no joint effect contributed by learning and KAM students to students' mathematical communication skills.

While Figure 2 which shows the interaction between KAM and student learning motivation can be seen in Figure 2, below: 


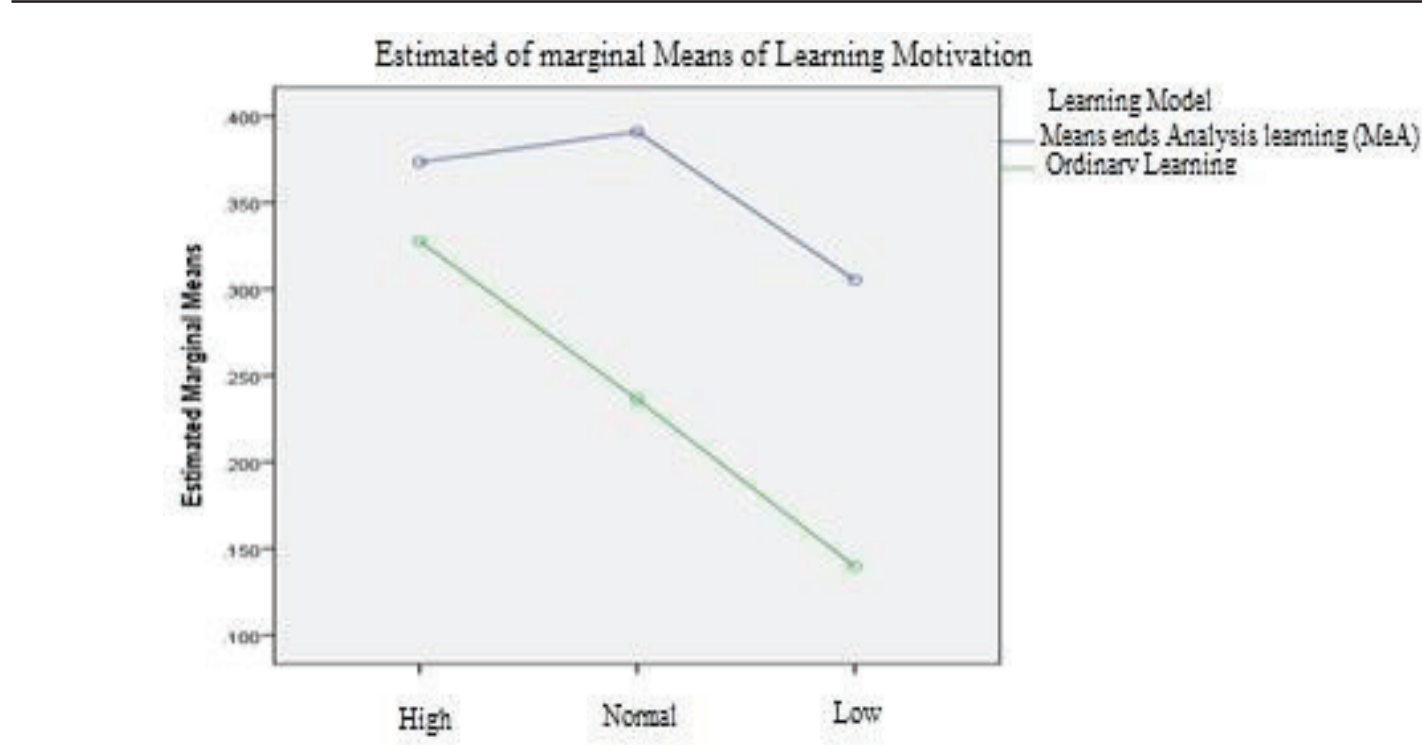

Figure 2. There is no interaction between the learning model and KAM students in influencing students' learning motivation.

Figure 2 above shows that there is no interaction between students' learning models and students' initial mathematical abilities towards increasing students' mathematics learning motivation. The difference in average increase in motivation to learn mathematics students who get Means Ends Analysis (MeA) learning model is more influential in achieving students' mathematics learning motivation because the average score obtained by students in Means Ends Analysis (MeA) learning is higher than the average score obtained on ordinary learning models. So that there is no interaction between the learning model and students 'initial mathematical abilities towards students' mathematical learning motivation can be seen clearly. This means that there is no joint effect contributed by learning and KAM students on student learning motivation.

\section{Conclusion}

Based on the results of the research described in the previous section, conclusions can be drawn as follows:

The improvement of students 'mathematical communication skills taught with Means ends Analysis (MeA) learning model is higher than the increase in students' mathematical communication skills taught with ordinary learning models.

The improvement of students 'mathematical learning motivation abilities taught with Means ends Analysis (MeA) learning model is higher than the increase in students' mathematical learning motivation abilities taught with ordinary learning models.

There is no interaction between the learning model and the initial mathematical ability (KAM) on improving students' mathematical communication skills.

There is no interaction between the learning model and the initial mathematical ability (KAM) on the increase in students' mathematical learning motivation.

There is no interaction between the learning model and the initial mathematical knowledge of students in influencing mathematical communication skills and student learning motivation means that the interaction between the learning model and the KAM of students (low, medium, and high) does not have a significant joint effect on mathematical communication skills and student learning motivation. So mathematical communication skills and student motivation are caused by differences in learning that are used not because of KAM students.

Mathematical communication skills and learning motivation of students whose learning using the Means Ends Analysis (MeA) learning model is better than conventional learning.

\section{References}

Ansari, B. I. (2009). Konsep dan Aplikasi Matematik. Banda Aceh: Yayasan PeNA Banda Aceh Divisi Penerbitan.

Antonius, C. P. (2006). Memahami Konsep Matematika secara Benar dan Menyajikannya dengan Menarik. Jakarta: Depdiknas.

Badan Standar Nasional Pendidikan (BSNP). (2006). Standar Isi untuk Satuan Pendidikan Dasar dan Menengah (Standar Kompetensi dan Kompetensi Dasar SMP/MTs). Jakarta: BSNP.

Choridah, D.T. (2013). Peran Pembelajaran Berbasis Masalah untuk Meningkatkan Kemampuan Komunikasi dan Berfiir Kreatif serta Disposisi Matematis Siswa SMA. artikel dalam INFINITY Jurnal Ilmiah Program 
Studi Matematika STKIP Siliwangi Bandung, Vol 2(2), pp. 194-202. Edisi September. Online jurnal di http://e-journal.stkipsiliwangi.ac.id/ index.php/infiity/article/view/35/34

Hamalik, O. (2003). Proses Belajar Mengajar. Jakarta: Bumi Aksara.

Hamzah B. U. (2009). Model Pembelajaran Menciptakan Proses Belajar Mengajar yang Kreatfi dan Efektif. Jakarta:Bumi Aksara.

National Council of Teachers of Mathematics (NCTM). (2004). Principles and Standards for School Mathematics. Reston. VA: NCTM

Sanjaya, W. (2009). Kurikulumdan Pembelajaran. Teori dan Praktik Kurikulum Tingkat Satuan Pendidikan (KTSP). Jakarta: Prenada Media Group.

Saragih, S. (2007). Mengembangkan Kemampuan Berpikir Logis dan Komunikasi Matematik Siswa Sekolah Menengah Pertama Melalui Pendekatan Matematika Realistik. Disertasi tidak diterbitkan. Bandung: Sekolah Pasca Sarjana UPI Bandung.

Slavin, Robert E. (2009). Psikologi Pendidikan. Teori dan Praktik. Jakarta: PT Indeks.

Soedjadi, R. (2004). Kiat Pendidikan Matematika di Indonesia. Dirjen Dikti, Jakarta.

Syahputra, Edi. (2016). Statistik Terapan. Medan: UNIMED PRESS. 